\title{
Qualitative Assessment of Fire Hazard Posed by Laminated Glass Balcony Balustrades on Fire Spread
}

\author{
Farah Binte Mohd Faudzi $\mathbb{D}^{*}$, Judith Schulz and Graham Dodd, Arup, 13 \\ Fitzroy Street, London W1T 4BQ, UK
}

Received: 10 September 2020/Accepted: 17 December 2020/Published online: 5 March 2021

\begin{abstract}
A qualitative assessment of fire hazard posed by laminated glass balcony balustrades was carried out through an in-depth analysis of empirical evidence from six (6) past balcony fires with glass balustrades to deduce the type of glass used and understand the mechanism for fire spread in these fire scenarios. Post-fire conditions of these balconies were studied based on their post-breakage integrity and presence of decolourisation/delamination in order to determine the type of glass used in these balconies. A visual observation of the overall fire spread during the fire and extent of damage post-fire was then carried out to determine whether there was a correlation between the type of glass used and the extent of fire spread. It was found that fire spread was mainly driven by combustible materials around the balcony construction as the fire damage on the balustrades was limited to the area in the vicinity of the combustible materials and the balustrade glass did not contribute to the fire. Given the current regulatory framework in England that limits the use of laminated glass in balcony balustrades from a fire safety perspective despite its architectural benefits and structural safety, this study shows that there is no evidence that the use of laminated glass would constitute a fire hazard when used as glazed balcony balustrading.
\end{abstract}

Keywords: Laminated glass, Balcony balustrade, Fire spread, Empirical evidence, Fire safety engineering

\section{Introduction}

Balconies are an architectural feature of a multi-storey building's façade, particularly in apartments to increase accessibility to outdoor spaces within dense urban environments. Balconies can increase the value and amenity of a property by not only improving the aesthetics but also enhancing natural ventilation and sun shading for thermal comfort and energy efficiency, mitigating noise pollution and providing access to outdoor space [1,2]. The importance of balconies has been further emphasised as they contribute to a healthy living environment deemed crucial after the outbreak of SARS in Asia [3] and the need to incorporate outdoor

\footnotetext{
*Correspondence should be addressed to: Farah Binte Mohd Faudzi, E-mail: farah.bintemohdfaudzi (a) arup.com
} 
spaces following the "value shift" in residential design due to the Coronavirus pandemic [4].

Glass balustrades are commonly used as a structural safety barrier along the edge of balconies while providing unobstructed views to facilitate visual connection with the external environment. Alternatives such as an opaque solid balustrade would reduce the amenity of the balcony by impeding the view and open balustrades such as metal railings pose other safety hazards such as potential for falling objects at height through the gaps in the railings and do not provide a wind-break function.

Laminated glass has mechanical properties that make it the preferred glass type compared to monolithic toughened glass for balcony balustrade application due to its post breakage robustness. The structural integrity of monolithic toughened glass is not maintained should it fail in service [5]. Once broken, the entire glass pane will crack or shatter into shards (size of shards is dependent on temper state) and will fall from its location presenting two risks: (1) the glass shards tend to fall in clumps and can fall onto people below and (2) the missing element of the balustrade presents an opening through which somebody could fall. However, laminated glass when properly designed is able to continue to function as a barrier even after the glass has fractured. The broken glass layers will remain in-situ providing containment on impact since they are held together by the interlayer and risk of falling glass is mitigated [6-8]. Furthermore, no opening would be created in the balustrade through which somebody could subsequently fall and the broken glass can remain in place until the replacement glass is installed.

However, the use of laminated glass has been questioned with regards to its potential contribution to external fire spread due to the current regulatory framework in place particularly in parts of the United Kingdom. The Building (Amendment) Regulations 2018 Regulation 7(2) states that: "materials which become part of an external wall, or specified attachment, of a relevant building are of European Classification A2-s1, d0 or A1 as classified in accordance with BS EN 135011:2007 + A1:2009" where "a balcony attached to an external wall" is a "specified attachment" [9]. This would suggest that balcony balustrades would be required to achieve Class A2-s1, d0 or A1 even though "window frames and glass" are exempted from Regulation 7(2). This was further clarified by the Technical Policy Division from the Ministry of Housing, Communities and Local Government (MHCLG) through an interview with Local Authority Building Control (LABC) [10]. Therefore, the use of laminated glass as balcony balustrades in certain building types in England would at the time of writing only be permitted if the product were able to achieve Class A2-s1, d0 or A1 classification.

\subsection{Review of the Performance Criteria Required to Achieve Class A2-s1,d0 or A1 for Laminated Glass}

Laminated glass is defined in BS EN ISO 12543-1:2011 as an "assembly consisting of one sheet of glass with one or more sheets of glass and/or plastic glazing sheet material joined together with one or more interlayers" [11]. Glass can be classified as Class A1 according to the European Commission Decision 96/603/EC (as 
amended by $2000 / 605 / \mathrm{EC}$ and $2003 / 424 / \mathrm{EC}$ ) which is a permitted method of demonstrating compliance to BS EN 13501-1:2018 under Classification Without Further Testing (CWFT) [12, 13]. Although laminated glass is included as glass within the European Commission Decision 96/603/EC, it is fundamentally not compliant with the limitations of applications set out in the General notes section of the European Commission Decision 96/603/EC since the interlayers will always exceed the limitation of applicability of $0.1 \%$ by volume of the laminated glass typically used in balcony balustrade applications. For double-layer laminated glass normally used in a balustrade in-fill panel, the thickness of the glass sheets varies typically between 7.5 and $12.8 \mathrm{~mm}$ typically and for free-standing glass barriers the glass thickness may be up to $31.5 \mathrm{~mm}$ [6] while the thickness of the interlayer varies between $0.38 \mathrm{~mm}$ and $6 \mathrm{~mm}$, in multiples of 0.38 (most commonly $1.52 \mathrm{~mm}$ with heat treated glass) [14] which implies that the interlayer would form a minimum of $3.7 \%$ by volume of the laminated glass (i.e. two layers of $10 \mathrm{~mm}$ glass with $0.76 \mathrm{~mm}$ of interlayer in between representing a practical minimum proportion of interlayer to glass). Therefore, the view by regulators in England is that laminated glass as a product has to be tested in order to achieve reaction-to-fire classification in accordance to BS EN 13501-1.

If the interlayer material is $<1 \mathrm{~mm}$ thick or has a mass per unit area of $<1 \mathrm{~kg} /$ $\mathrm{m}^{2}$, the Class A2 limit for calorific potential set in Table 1 of EN 13501-1 of $4 \mathrm{MJ} / \mathrm{m}^{2}$ would apply as it is classified as a non-substantial component. Otherwise the limit is $3 \mathrm{MJ} / \mathrm{kg}$ when classified as a substantial component [13].

The interlayer material typically used in laminated glass is a material called polyvinyl butyral (PVB). Other materials that can be used are ionomer (SentryGlas), ethylene-vinyl acetate (EVA), cast-in-place resin (CIP) or thermoplastic polyurethane (TPU) $[6,8,14]$. The calorific potential for the different interlayer materials are tabulated in Table 1.

Using PVB as a reference, the calorific potential of the interlayer was benchmarked against the A2 limit set in BS EN 13501-1 for a range of PVB thicknesses as shown in Table 2.

As can be seen from the Table 2, it is impossible for laminated glass using a PVB interlayer to meet the Class A2, s1-d0 limit for heat of combustion using the test classification of BS EN 13501-1 as the calorific potential of the PVB interlayer

\section{Table 1}

\section{Calorific Potential of Different Interlayers Used in Laminated Glass}

\begin{tabular}{llc}
\hline Interlayer material & \multicolumn{1}{c}{ Calorific potential (MJ/kg) } & Source \\
\hline Polyvinyl butyral (PVB) & 32.90 & {$[15]$} \\
Ionomer (SentryGlas) i.e. ionically cross-linked ethy- & 46.2 to 46.5 & {$[15]$} \\
$\quad$ lene copolymer & 40 & {$[16]$} \\
Ethylene-vinyl acetate (EVA) & 40 & {$[15]$} \\
Cast-in-place (CIP) resin e.g. polyester, polymethyl & 21.6 to 29.8 (polyester) 26.64 (poly- & methacrylate) \\
$\quad$ methacrylate etc & 23.90 & {$[15]$} \\
Thermoplastic polyurethane (TPU) & & \\
\hline
\end{tabular}




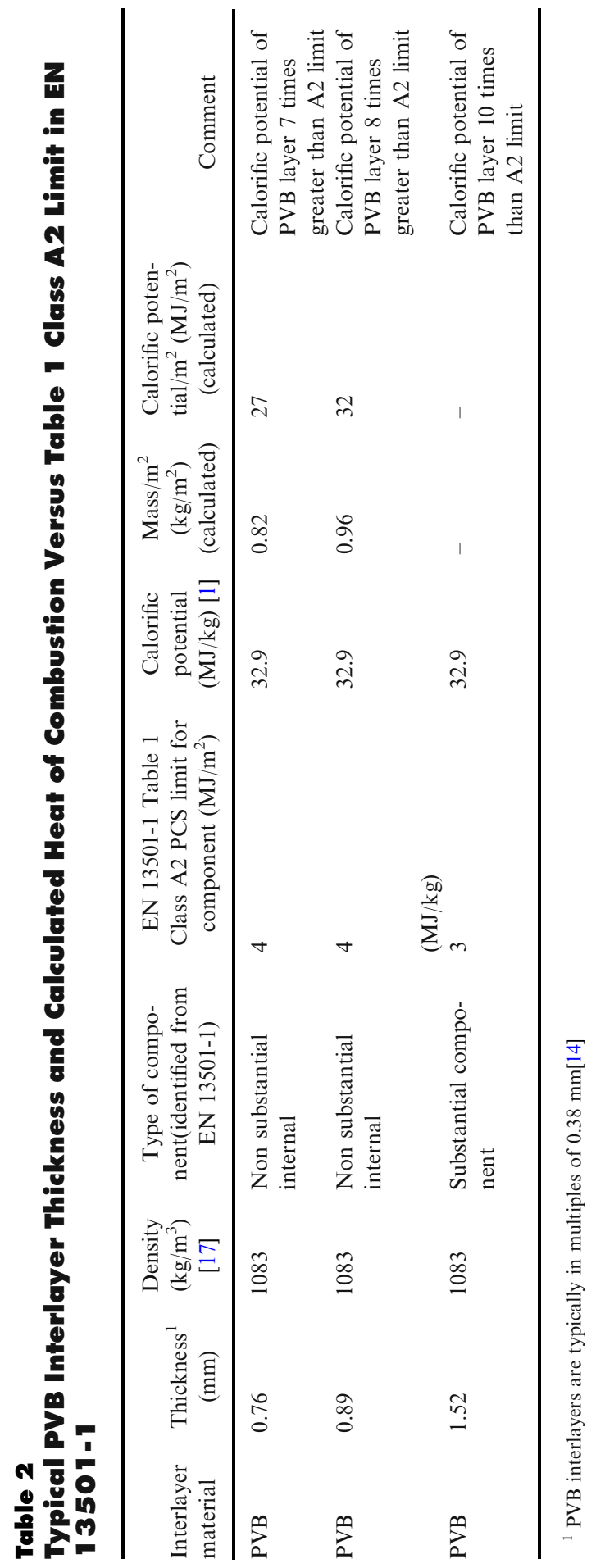


will always exceeds the A2 limit set in EN 13501-1 when tested. The tabulated calorific potential in Table 1 also shows that other alternative interlayer materials would also exceed the A2 limit set in EN 13501-1.

Therefore, laminated glass in the current regulatory framework would not be able to meet the performance requirement i.e. Class A2-s1, d0 or A1 in accordance to BS EN 13501-1. This has led to warranty providers such as National House Building Council in the United Kingdom rejecting the use of laminated glass as balcony balustrades [18].

Given the architectural value of glass balustrades and the structural benefits of particularly laminated glass for balcony balustrades application, there is a need to assess whether the use of laminated glass poses a valid significant risk for fire safety concern that should restrict its use.

Therefore, a further assessment of fire hazard posed by glass balustrades on balconies is required in order to establish a fundamental understanding on whether the use of laminated glass poses a significant risk for fire spread.

\subsection{Review of Small-Scale Experimental Work Involving Laminated Glass}

Over recent years, a number of experiments have been undertaken and published that study the reaction of laminated glass to localised fire exposure via small-scale experiments. These experiments do not follow a standard testing procedure.

Wang et al. [19] carried out experiments on single coated, insulated and laminated glazing to study the fire performance and breakage mechanisms of different kind of glazing. A $500 \times 500 \mathrm{~mm} \mathrm{~N}$-heptane pool fire providing a maximum heat release rate (HRR) of $300 \mathrm{~kW}$ to model the thermal shock from a real fire scenario was placed $750 \mathrm{~mm}$ away a $600 \times 600 \mathrm{~mm}$ glass pane. The single coated float glass was $6 \mathrm{~mm}$ thick. The laminated glass pane consists of 2 layers of $6 \mathrm{~mm}$ thick float glass with a $0.38 \mathrm{~mm}$ thick PVB interlayer. It was observed that both the internal and external glass panes broke at a critical heat flux of $10 \mathrm{~kW} / \mathrm{m}^{2}$ and $14 \mathrm{~kW} / \mathrm{m}^{2}$ respectively for the tests with laminated glazing, however the overall glass assembly remained intact in its supporting frame. However, fallout occurred in tests with the single float glass pane which broke at a critical heat flux of $10 \mathrm{~kW} / \mathrm{m}^{2}$. Bubbling of the interlayer within the laminated glass sample was observed and it was predicted that the interlayer would be pyrolyzed and carbonised releasing toxic smoke with extended exposure to fire. However, there was no flaming of the interlayer recorded.

Similar results were observed from experiments by Debuyser et. al. [20] where $285 \times 185 \mathrm{~mm}$ monolithic and laminated glass panes of various thickness and interlayer material were exposed to fire conditions simulated by a radiant panel with incident heat flux kept mainly at $8 \mathrm{~kW} / \mathrm{m}^{2}$ to $12 \mathrm{~kW} / \mathrm{m}^{2}$. Thermal fractures occurred at a lower temperature gradient across the thickness of the glass pane for monolithic specimens compared to laminated glass. Bubbling of the interlayer was observed for the laminated glass with no fall-out of glass or subsequent flaming observed although decolourisation and charring of the interlayer was observed.

These small-scales experiments by Wang et al. and Debuyser et al. reveal how the advantages in structural integrity for laminated glass would also apply in a fire 
scenario. Furthermore, they reveal the visual difference when laminated glass is exposed to fire due to the reaction of the interlayer forming bubbles and decolourisation. Although there was no adverse reaction to fire for laminated glass i.e. sustained flaming, it remains unclear if this observation can be extrapolated in a real fire scenario where laminated glass is used within a balcony balustrade.

Therefore, this study has also included the evaluation of photographic evidence from real fire incidents where balconies with glass balustrades were involved in the fire to obtain a fundamental understanding of the fire hazard presented by the use of laminated glass to form the balustrades of a balcony. Through a qualitative analysis of the available information from actual fires, this study provides a better understanding of the behaviour of laminated glass under fire conditions in actual application as balustrades for balconies beyond standard prescribed testing.

\section{Methodology}

Reference case studies of past balcony fires with glass balustrades were collated according to availability of information with a focus on visual photographic evidence that could be analysed. Six (6) balcony fires from three (3) countries were shortlisted for further analysis as shown in Table 3.

In the absence of construction details of the balconies within these buildings, the first phase of the analysis was carried out with a multi-disciplinary team of fire, façade and material experts from Arup to determine the type of glass used [27]. Characteristics of the glass was observed based on post-fire conditions from the photographic evidence to determine whether the balustrades were laminated glass or monolithic glass as shown in Table 4. Observations on post-breakage integrity and presence of decolourisation/delamination were recorded as characteristics that differentiated laminated from monolithic glass. It was noted that the type of fixing used and/or edge supports are not characteristics that reliably differ between the application of the two glass types, and so was not taken into consideration when identifying the glass type.

The next phase of the study involves analysing the overall development of the fire through interpretation of images taken during the fire incident as well as the damage post-fire. This is to identify potential drivers for fire spread and deduce if

\section{Table 3}

\section{List of Balcony fires to be Analysed (Listed in Chronological Order)}

\begin{tabular}{lllll}
\hline Fire incident no. & \multicolumn{1}{c}{ Location } & \multicolumn{1}{c}{ Building name } & Date of fire incident & Source \\
\hline 1 & Melbourne, Australia & Lacrosse Docklands & 25 November 2014 & {$[21]$} \\
2 & Manchester, UK & The Lighthouse & 30 December 2017 & {$[22]$} \\
3 & London, UK & West Hampstead Square & 3 July 2018 & {$[23]$} \\
4 & London, UK & Primula Court & 21 September 2019 & {$[24]$} \\
5 & Ontario, Canada & Springbank Manor & 27 September 2019 & {$[25]$} \\
6 & Toronto, Canada & Emerald City Condos & 30 September 2019 & {$[26]$} \\
\hline
\end{tabular}




\section{Table 4}

Characteristics of Class on Post-Fire Conditions

\begin{tabular}{|c|c|c|}
\hline Characteristics & Laminated glass & Monolithic glass \\
\hline $\begin{array}{l}\text { Post-breakage integrity } \\
\quad([7,28])\end{array}$ & $\begin{array}{l}\text { Large fragments remaining fixed on } \\
\text { frame }\end{array}$ & $\begin{array}{l}\text { Limited remnants on frame as it is } \\
\text { expected to completely shatter upon } \\
\text { failure }\end{array}$ \\
\hline $\begin{array}{l}\text { Presence of decolourisa- } \\
\text { tion/delamination } \\
([19,20])\end{array}$ & $\begin{array}{l}\text { Visible loss of transparency due to } \\
\text { delamination and bubbling of inter- } \\
\text { layer }\end{array}$ & $\begin{array}{l}\text { Remain fully transparent (if intact) } \\
\text { other than deposit of soot on surface }\end{array}$ \\
\hline
\end{tabular}

there are any notable indicators that would point to the laminated glass contributing to the spread of the fire. The key observations would be:

(a) Evidence of extent of fire and smoke damage around the balcony (burn patterns, soot deposits, heat damage);

(b) Evidence of fire damage along glass balustrades (presence of decolourisation, delamination, glass fall out);

(c) Evidence of other combustible materials on the balcony that may have contributed to fire spread (combustible cladding, items stored on the balcony); and

(d) Discussion of other contributing factors that could have led to glass damage (e.g. fire fighting intervention).

Through this qualitative assessment focussing on real fire situation, an understanding of the behaviour of laminated glass on balcony balustrades could inform whether it pose a significant risk to external fire spread on buildings. The overall framework of this analysis is summarised in Fig. 1.

\section{Results and Discussion}

\subsection{Type of Glass Used in Balustrades}

Images from the fire incidents were analysed according to key characteristics (Table 4) and the results are shown in Table 5. The characteristics are colourcoded to ease identification on the images as evidences of post break integrity are marked up in red and presence of decolourisation/delaminated are marked up in yellow.

The glass used as balustrade for Fire 1 and Fire 4 have been identified as laminated glass. The post-fire images for Fire 1 [Fig. 2 (left)] shows that the part of the laminated glass panes were able to retain its integrity supported by the frame

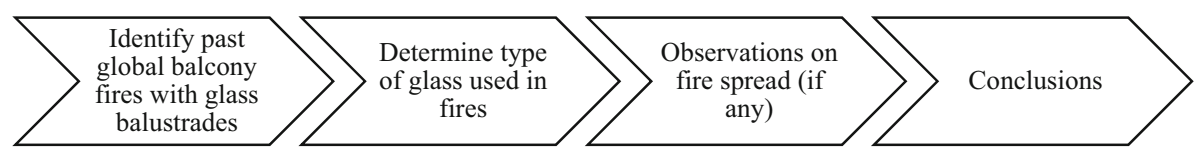

Figure 1. Framework of study. 


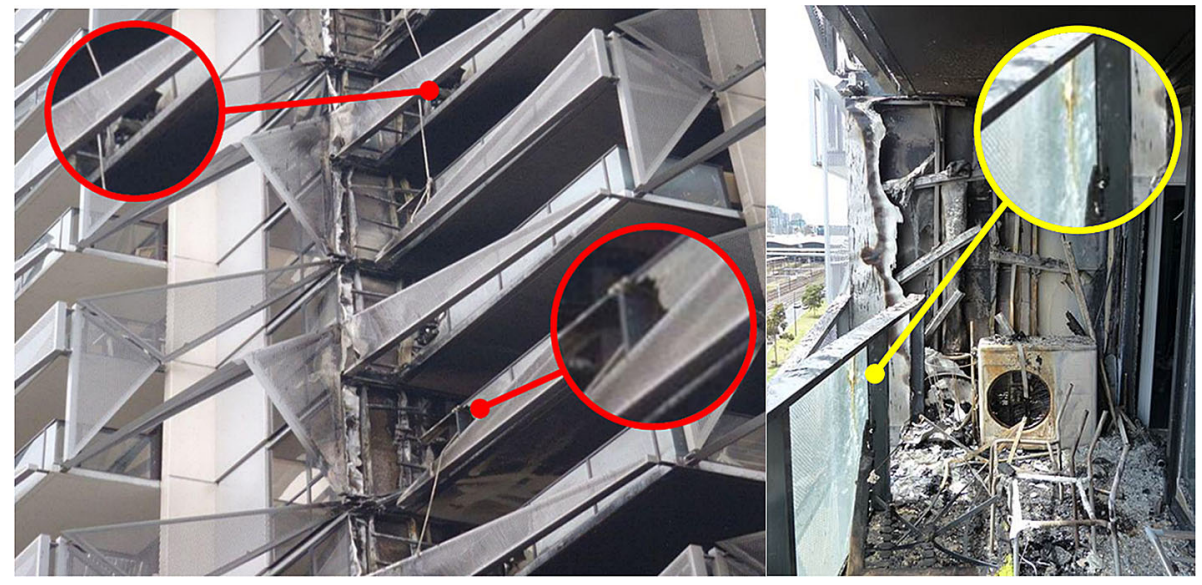

\section{Figure 2. Fire 1. Original images credited to Metropolitan Fire Brigade (with permission) [2 1].}

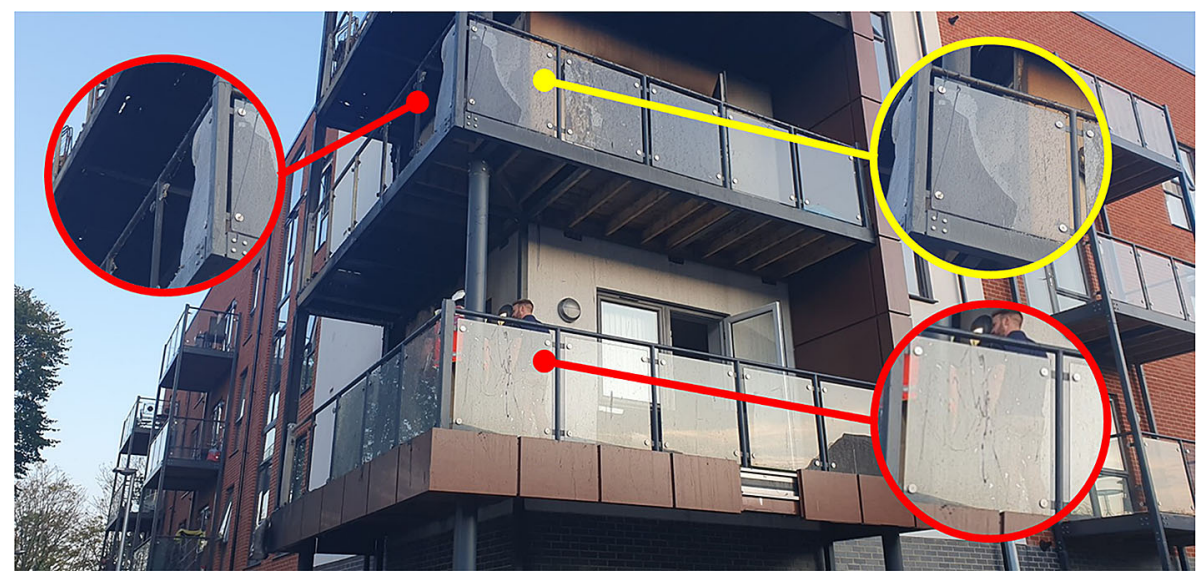

\section{Figure 3. Fire 4. Original image credited to The Havering Daily (with permission). [24].}

although the rest of the pane has fallen away. This is similarly observed in post fire images of Fire 4 (Fig. 3) where part of the laminated glass could still retain its integrity even with only point supports. In addition, there are crack patterns on the glass panels which indicates that there is a presence of an interlayer that prevents fall out which was similarly observed in the small-scale experiments by Wang et al. [19]. For both fires, the presence of an interlayer was also observed due to the visual evidence of reaction of the organic interlayer with heat. A char stain line in Fig. 2 (right) is similar to the observations of charring along crack lines in the small scale experiments by Debuyser et al. [20]. The wave-like pattern 
(a)

(c)

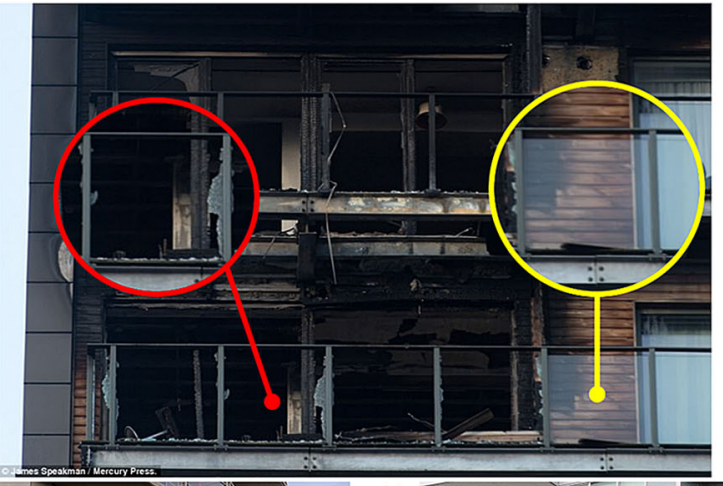

(b)

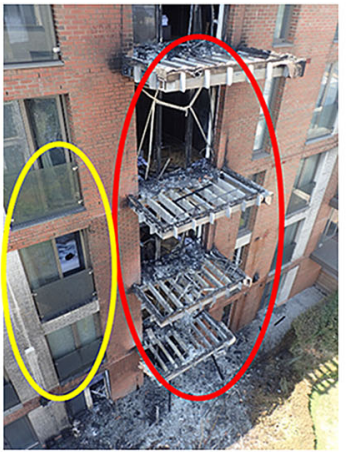

)

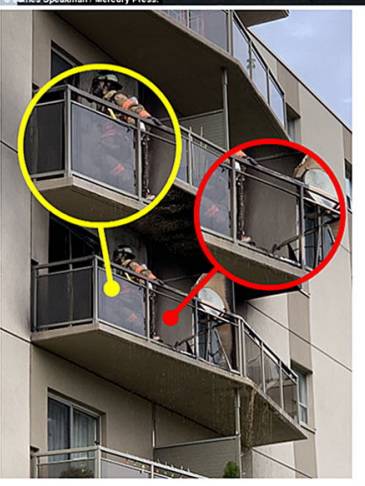

(d)

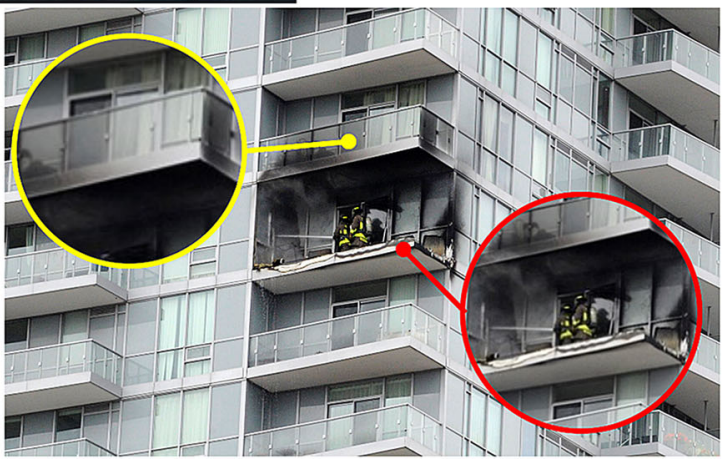

Figure 4. (a) Fire 2. Original image credifed to Caters News Agency Ltd. (with permission) [22] (b) Fire 3. Original image credited to London Fire Brigade (with permission). [23] (c) Fire 5. Original image credifed to @EventPhotoMan (with permission). [25] (d) Fire 6. Original image credited to Dan Pearce/Torstar (with permission). [26].

in Fig. 3 also indicated that there is presence of delamination within the glass panes due to exposure to heat from the fire. Therefore, it can be deduced that the glass involved in Fires 1 and 4 are laminated glass.

Conversely, monolithic glass is used in Fires 2, 3, 5 and 6 as shown in Fig. 4. This is represented by the complete fall-out of glass panes post-fire owing to its poor post-breakage integrity. In Fire 2, although there are remnants of glass held by the supports, the uneven edges indicate that the glass has shattered during the fire instead of cracked into fragments. Furthermore, for these fires, the unaffected glass panes did not show any indication of delamination or charring. For Fire 3, the London Fire Brigade study [23] stated that the balconies are constructed of "toughened balustrade glazing" which supports the visuals findings. Therefore, these balconies do not have laminated glass balustrades. 
Table 5

Matrix to determine type of glass for each fire incident

\begin{tabular}{lllll}
\hline $\begin{array}{l}\text { Fire incident } \\
\text { no. }\end{array}$ & $\begin{array}{c}\text { Post breakage } \\
\text { Integrity }\end{array}$ & $\begin{array}{c}\text { Presence of decolourisation/de- } \\
\text { lamination }\end{array}$ & $\begin{array}{c}\text { Laminated } \\
\text { glass? }\end{array}$ & $\begin{array}{c}\text { Reference fig- } \\
\text { ures }\end{array}$ \\
\hline 1 & Yes & Yes & Yes & Figure 2 \\
2 & No & No & No & Figure 4 \\
3 & No & No & No & Figure 4 \\
4 & Yes & Yes & Yes & Figure 3 \\
5 & No & No & No & Figure 4 \\
6 & No & No & No & Figure 4 \\
\hline
\end{tabular}

\section{Table 6}

\section{Matrix to analyse fire spread mechanisms}

\begin{tabular}{|c|c|c|c|c|c|c|}
\hline $\begin{array}{l}\text { Fire } \\
\text { incident } \\
\text { no. }\end{array}$ & $\begin{array}{l}\text { Laminated } \\
\text { glass? } \\
\text { (Sect. 3.1) }\end{array}$ & $\begin{array}{l}\text { Overall fire } \\
\text { spread } \\
\text { away from } \\
\text { balcony of } \\
\text { origin }\end{array}$ & $\begin{array}{c}\text { Presence of } \\
\text { other com- } \\
\text { bustible } \\
\text { materials }\end{array}$ & $\begin{array}{l}\text { Details of construc- } \\
\text { tion in balcony area }\end{array}$ & $\begin{array}{c}\text { Fire } \\
\text { spread } \\
\text { along } \\
\text { balustrades }\end{array}$ & $\begin{array}{l}\text { Reference } \\
\text { figures }\end{array}$ \\
\hline 1 & Yes & Yes & Yes & $\begin{array}{l}\text { "Aluminium/poly- } \\
\text { ethylene composite } \\
\text { panel façade" [21] lin- } \\
\text { ing one end of the } \\
\text { balcony wall }\end{array}$ & No & Figure 5 \\
\hline 2 & No & Yes & Yes & $\begin{array}{l}\text { "Wooden balconies" } \\
\text { [22] Timber decking } \\
\text { and timber lined } \\
\text { external walls (by } \\
\text { observation) }\end{array}$ & No & Figure 7 \\
\hline 3 & No & Yes & Yes & $\begin{array}{l}\text { "steel frame with alu- } \\
\text { minium facia and } \\
\text { composite decking } \\
\text { and plastic soffits" } \\
\text { [23] }\end{array}$ & No & Figure 8 \\
\hline 4 & Yes & Yes & Yes & $\begin{array}{l}\text { Aluminium composite } \\
\text { panel framing the bal- } \\
\text { conies with timber } \\
\text { decking (by observa- } \\
\text { tion) }\end{array}$ & No & Figure 6 \\
\hline 5 & No & No & No & $\begin{array}{l}\text { Concrete walls and } \\
\text { floor (by observation) }\end{array}$ & No & Figure 9 \\
\hline 6 & No & No & No & $\begin{array}{l}\text { Concrete walls and } \\
\text { floor (by observation) }\end{array}$ & No & Figure 9 \\
\hline
\end{tabular}



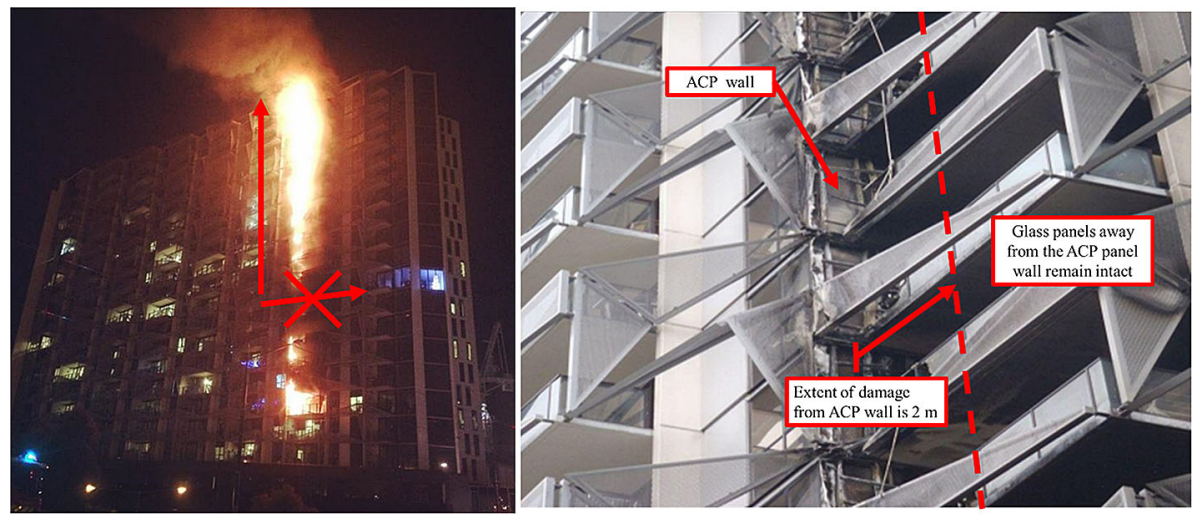

\section{Figure 5. Fire spread in Fire 1 . Original images credited to Metropolitan Fire Brigade (with permission) [21].}

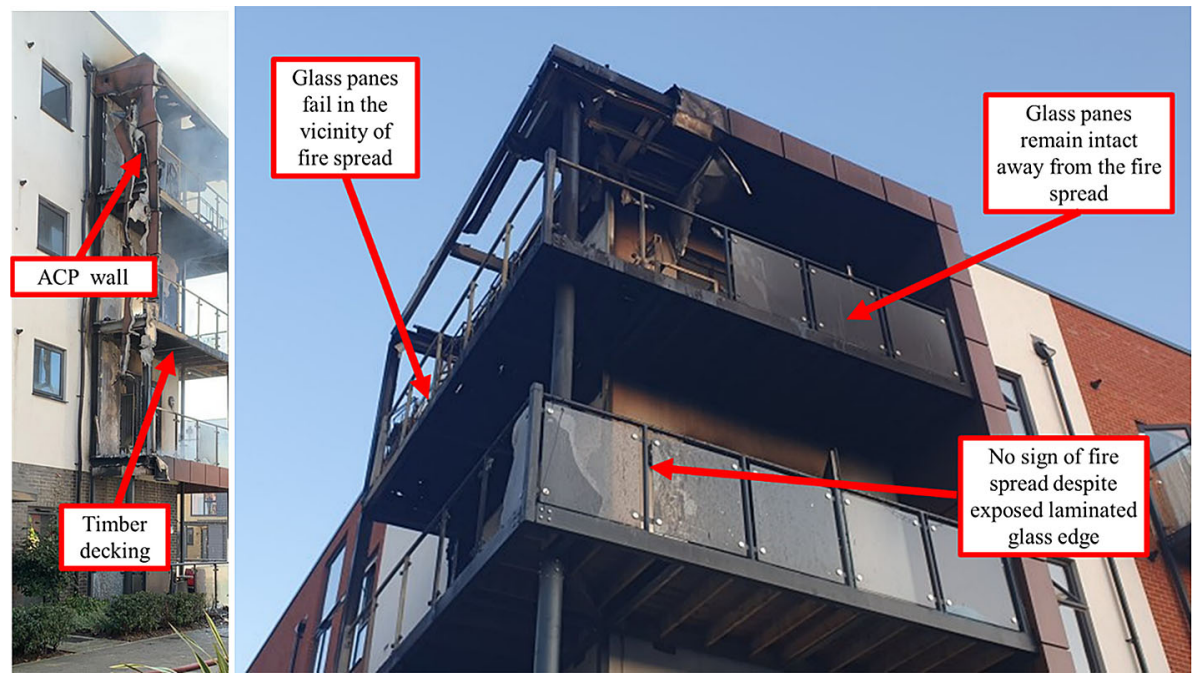

\section{Figure 6. Fire spread in Fire 4. Original images credited to The Havering Daily (with permission) [24].}

\subsection{Fire Spread Observations}

The results of the analysis on pre and post-fire images from these balcony fires are tabulated in Table 6. Extrapolating the results from Sect. 3.1, it is evident that the fire spread phenomenon is more likely to be derived based on the presence of other combustible materials rather than the type of glass used for the balustrade.

For Fire 1, there was extensive vertical fire spread across 14 floors which has been reported to be attributed to the combustible external aluminium composite panel (ACP) and contribution of the glass balustrade was not discussed as a relevant factor by the Metropolitan Fire Brigade [21]. The cluttered balconies used as 


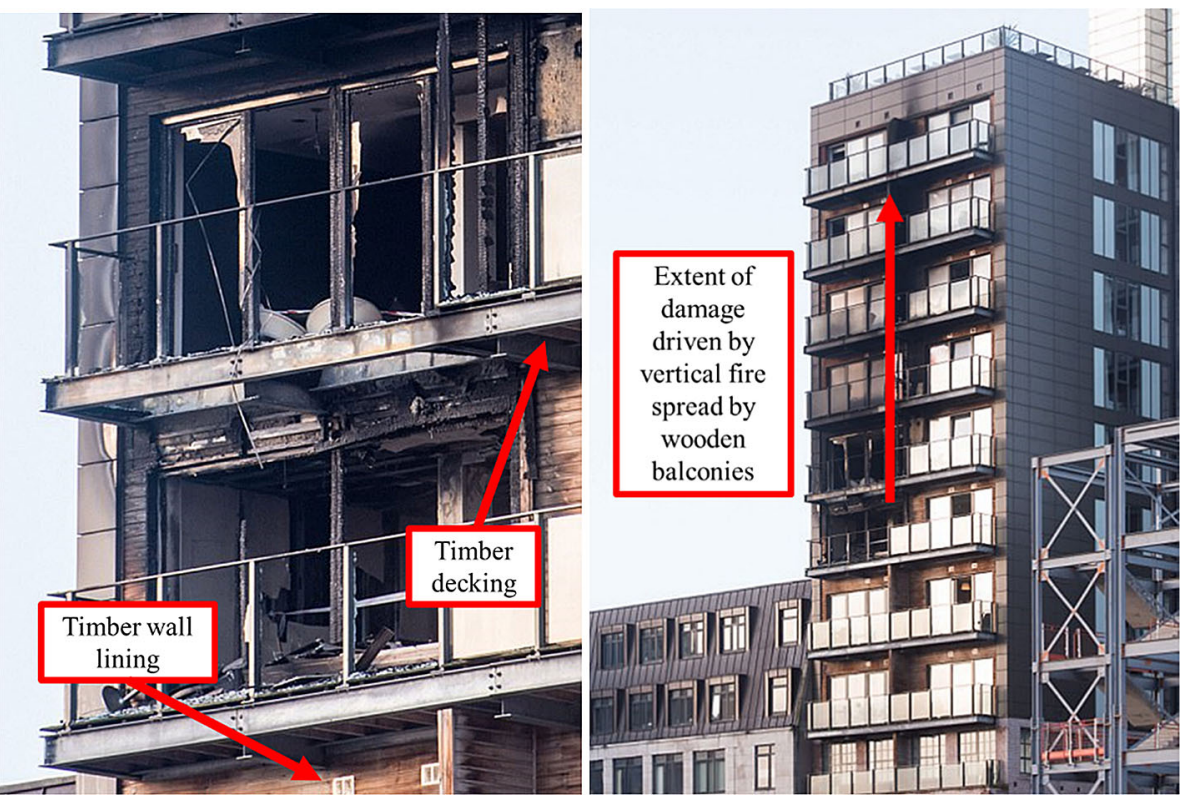

Figure 7. Fire spread in Fire 2. Original image credited to Caters News Agency Ltd (with permission) [22].
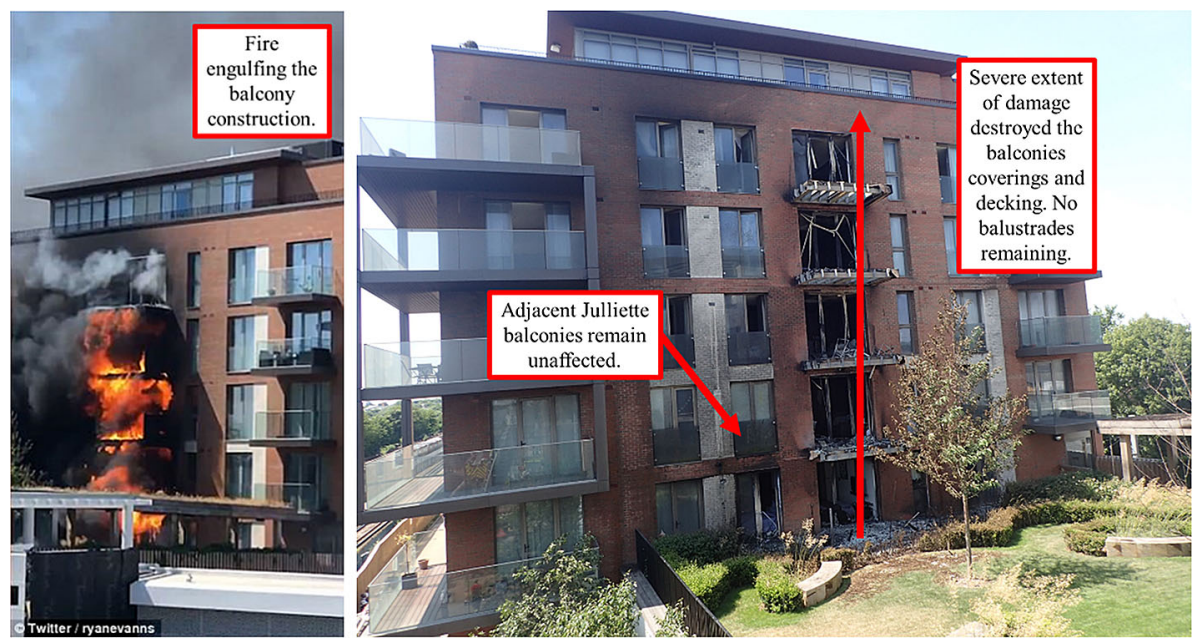

Figure 8. Fire 3. Original images credifed to @ryanevanns (with permission) [30] (left) and London Fire Brigade (with permission) [23] (right). 
(a)

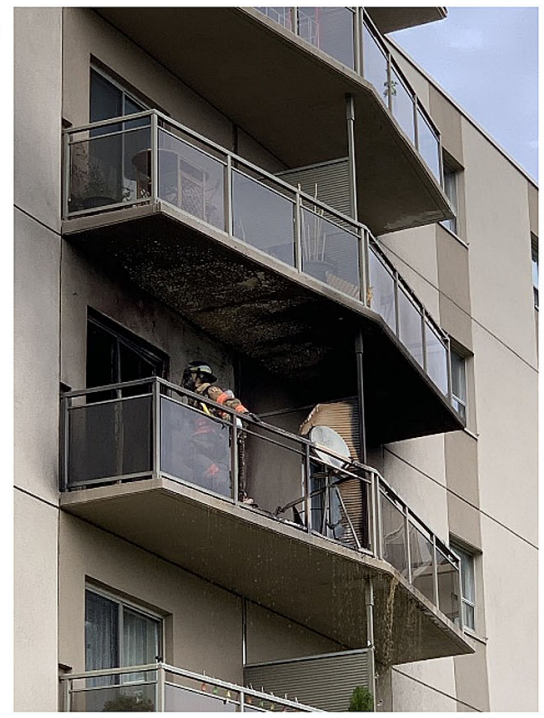

(b)

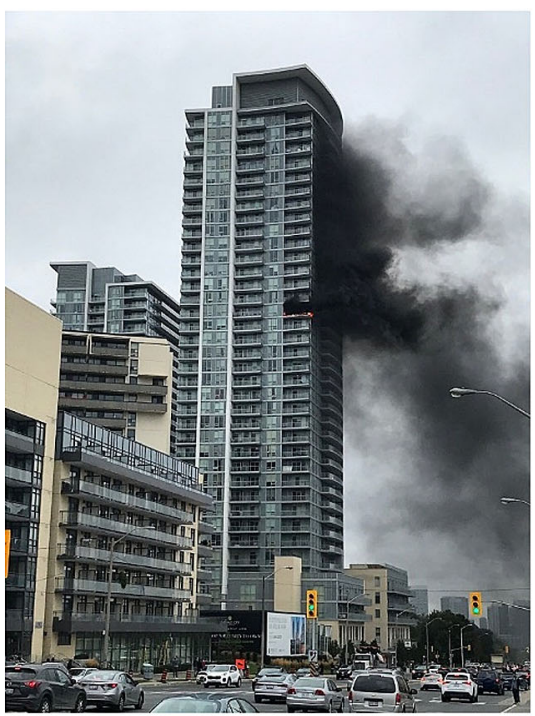

Figure 9. (a) Fire 5 (b) Fire 6 . No fire spread beyond balcony of origin for Fires 5 and 6 . Images credited to @EventPhotoMan (with permission) [25] for (a) and Ken Pearson/Torstar (with permission) [26] for (b).

storage for the residents' belongings also contributed to the fire load within the balconies [29]. From the photographic evidence within the report as shown in Fig. 5, it is observed that only the glass panels in direct contact with the flames are affected as indicated by the broken panels in relation to the fire spread. There is limited fire spread horizontally and adjacent panels not within the direction of fire spread remain intact. This shows that the glass balcony does not facilitate fire spread along the balcony balustrade even when directly exposed to a severe external ACP cladding fire spanning 14 floors. It was reported that the Metropolitan Fire Brigade arrived on scene 5 min after responding to an apartment fire call and observed that the fire has spread up the external walls and balconies over 6 floors.

For Fire 4 (Fig. 6), the L-shaped balcony at the corner of a building is closed off on the side by ACP cladding with a timber decking structure. The fire spread from the first-floor balcony to the upper floor facilitated by the ACP cladding on one end of the balcony. The fire damage on the glass balustrade is limited to 4 panels which are broken, extending to $4 \mathrm{~m}$ away from the fire in the ACP wall. The remaining glass balustrade remains intact although the exposure to heat from the fire shows significant cracking of the glass, as well as some burn-off of the interlayer. Therefore, there is no indication that the fire propagated via the glass balustrades, which remain intact even though the open edges between panes are in close proximity with the interlayer exposed.

In Fire 2, the balustrades are not constructed of laminated glass but there is significant fire spread vertically across 3 floors externally via the wooden balconies as 
seen from observed fire damage and charring on the timber decking and timber wall lining as shown in Fig. 7. This further supports the findings in Fires 1 and 4 that a laminated glass balustrade does not have a significant impact on fire spread in comparison to other combustible materials that form part of the external wall construction in the balcony area.

Similarly for Fire 3, there was significant fire spread that damaged all balconies above and below the seat of fire with "only the steel frame remaining" [23]. Although the fire started from the 3rd floor balcony, it spread vertically to the balconies on 4th to 6th level and falling debris damaged the lower 2nd level balcony as well. Although the full construction of the balcony was involved in the fire except the steel frame, there was no lateral flame spread due to the brickwork façade and the Juliet balconies adjacent to the balcony remain unaffected except for staining from soot. From the photographic evidence during the fire, it can be seen that the flames are engulfing the entire balcony construction which can be attributed to the materials used in the construction of the balcony (Fig. 8).

The importance of a non-combustible balcony construction is shown in Fires 5 and 6 where the fire spread is limited to the balcony of origin as shown in Fig. 9. No information was available on the time to fire service intervention and its effect on the glass balustrades.

Based on the above analysis, there is no evidence from past balcony fires that the interlayer within laminated glass balustrades contributes to fire spread or growth of the fire. Fire spread is mainly driven by combustible materials around the balcony construction i.e. combustible cladding material or wooden deck. The fire damage on the balustrades was limited to the area in contact with the fire while the adjacent glass balustrades, that were approximately $1 \mathrm{~m}$ to $2 \mathrm{~m}$ away from the contributing combustible materials, remained intact and did not contribute the fire (i.e. Fires 1 and 4). This phenomenon is also evident when monolithic toughened glass is used (i.e. Fire 2). Therefore, there is no justification that the use of laminated glass would constitute a fire hazard when used as glazed balcony balustrading, compared to a monolithic glass without a laminate interlayer.

It is notable however that for monolithic glazing, entire glass panes fail during significant fire exposure, resulting in a greater risk of falling from the now missing balustrade barrier. Fragments of monolithic toughened glass also present a hazard to those below when they fall, either through damage by fire or when broken by any other cause. This emphasises the safety risks posed by the use of monolithic balustrade glazing identified by SCOSS in their Safety Alert on glass in balustrades and highlighted in CROSS report 741. [5, 31].

\section{Conclusion}

Glass has a highly beneficial role in the construction of balconies, as a balustrade material providing visual connection, protection and shelter. Laminated glass is the only acceptable type of glass for this application as it enhances the role of balconies while providing appropriate safety. Laminated glass has mechanical properties that make it the preferred glass type compared to monolithic toughened glass 
for balcony balustrade application due to its post breakage robustness which is essential in life safety. Due to the material composition of laminated glass, it is a composite material that does not fit in the European Commission Decision (Classified without Further Testing) nor the European Classification routes for reaction-to-fire performance.

This study has shown from an analysis of past fire incidents that there is no correlation between the use of laminated glass and the incidence of fire spread from the balcony of origin. No evidence was found from our study that laminated glass as balcony balustrade has any significant contribution to fire spread that would warrant a ban on its use. Therefore, the application of laminated glass as balcony balustrade does not pose a risk in terms of external fire spread.

However, it must be noted that this cannot be extrapolated to other applications of laminated glass on facades. There is a need to understand the behaviour of laminated materials including laminated glass for specific applications. Behaviour of such products would differ based on exposure to different fire conditions. The inherent nature of laminated materials due to the combustible content of the laminates result in more complex behaviours in fire considerations and are dependent on characteristics such as type of laminates, how its enveloped etc. Therefore, this analysis and its findings are specific only to the use of laminated glass in balcony balustrades.

This study also provides a case study to explore a novel method for fire research. It showcases the potential in utilising subject matter experts in the field of fire and material science as well as empirical evidence from relevant past fires to provide an efficient appraisal of risk. Adoption of this method in applications where there is sufficient empirical evidence to support the study would allow for more regular feedback loops to be created from real fire incidents to inform research needs. This, in turn, could assist in providing evidence to inform decisions on resources allocation where experimental tests are needed in the absence of adequate empirical evidence. In the context of studying the risk of laminated glass on balcony balustrades, there is sufficient post-fire evidence to determine that laminated glass does not pose a considerable hazard as a balcony balustrade and resources for experimental fire tests could therefore be allocated towards the study of more large-scale applications of laminated glazing such as use in spandrel panels.

\section{Acknowledgement}

The authors would like to express their gratitude to Tom Parker from Arup Fire for his guidance and expertise in material testing and the regulatory framework. The authors would also like to thank Peter Lenk, Laura Sims and Darren Kent from Arup Facades as well as Emma McIntyre from Arup Fire for providing their expertise in reviewing the photographs from the different fire incidents. The authors would also like to thank Paul Carstairs, the Arup Photo Librarian for his assistance in sourcing the photographs and all owners of the photographs used in this paper as credited for granting permission to reproduce these photographs for the paper. 


\section{References}

1. Kwong WC, Siu KW, Chung YY (2004) The value of the provision of a balcony in apartments in Hong Kong. Prop Manag 22(3):250-264. https://doi.org/10.1108/ 02637470410545020

2. Anderson B (2019) What features do apartment renters value most?, National real estate invester. https://www.nreionline.com/multifamily/what-features-do-apartment-rent ers-value-most (Accessed Sep 09, 2020)

3. Chan E, Yiu CY, Baldwin A, Lee G (2009) Value of buildings with design features for healthy living: a contingent valuation approach. Facilities 27(5-6):229-249. https:// doi.org/10.1108/02632770910944952

4. Marcus F (2020), Housing after coronavirus should feature more balconies says Alison Brooks, de zeen. https://www.dezeen.com/2020/05/19/alison-brooks-housing-coronavir us-balconies/. Accessed 09 Sep 2020

5. Standing Committee on Structural Safety (2020) SCOSS Alert - Structural safety of glass in Balustrades, 2019. Accessed: Sep 09 2020. https://www.structural-safety.org/me dia/694762/scoss-alert-structural-safety-of-glass-in-balustrades.pdf

6. O'Regan C (2015) Structural use of glass in buildings, no. 2nd Edition

7. O'Connor D (2016) The building envelope: fire spread, construction features and loss examples, pp. 3242-3282

8. Keiller A, Walker A, Ledbetter S, Wolmuth W (2005) Guidance on glazing at height. CIRIA

9. Secretary of State (2018) The building (Amendment) regulations 2018. Ministry of Housing, Communities and Local Government

10. LABC (2019) Brian Martin from MHCLG advises on amendments to the building regulations in 2018, YouTube. https://www.youtube.com/watch?v $=$ Nx8WUJLPuEA\&feat ure $=$ youtu.be\#t $=3$ m53s. Accessed 09 Sep 2020

11. ISO/TC 160/SC 1 Product considerations, ISO 12543-1:2011 Glass in building - Laminated glass and laminated safety glass - Part 1: Definitions and description of component parts, 2nd ed. 2011

12. European Commission, Commission Decision Establishing the List of Products Belonging to Classes A "No Contribution to Fire." 1996

13. BSI (2018) BS EN 13501-1:2018 Fire classification of construction products and building elements - Part 1: classification using data from reaction to fire tests

14. Centre for the Protection of National Infrastructure (CPNI), "Introduction to Laminated Glass Interlayers: Guidance to raise awareness on which laminated glass interlayer types to use," 2019. https://www.cpni.gov.uk/system/files/documents/c3/4b/Intro_ Glass_Interlayers_060619.pdf Accessed 09 Sep 2020

15. Hurley MJ (2016) Appendix 3: fuel properties and conversion data, In SFPE Handbook of Fire Protection Engineering pp. 3437-3475

16. Glass for Europe (2015) Classification of reaction to fire of glass products: Recommendation from Glass for Europe. https://glassforeurope.com/wp-content/uploads/2018/04/ GfE-Reaction-to-fire-Position-Paper_April-2015.pdf. Accessed 09 Sep 2020

17. Carrot C, Bendaoud A, Pillon C (2005) Polyvinyl Butyral. In: Olabisi O, Adewale K (eds) Handbook of Thermoplastics, 2nd edn. CRC Press, Boca Raton, pp 89-137

18. NHBC (2019) Technical Extra 25, NHBC Standards http://www.nhbc.co.uk/NHBCpub lications/LiteratureLibrary/Technical/TechnicalExtra/filedownload,85532,en.pdf. Accessed 09 Sep 2020 
19. Wang Y, Wang Q, Wen JX, Sun J, Liew KM (2017) Investigation of thermal breakage and heat transfer in single, insulated and laminated glazing under fire conditions. Appl Therm Eng 125:662-672. https://doi.org/10.1016/j.applthermaleng.2017.07.019

20. Debuyser M, Sjöström J, Lange D, Honfi D, Sonck D, Belis J (2017) Behaviour of monolithic and laminated glass exposed to radiant heating. Constr Build Mater 130:212-229. https://doi.org/10.1016/j.conbuildmat.2016.09.139

21. Metropolitan Fire Brigade (2014) Post Incident Analysis Report

22. Robertson A, Southworth P, Murphy-Bates S, Manchester fire was spread by wooden balconies," DailyMail Online, Dec. 31, 2017. https://www.dailymail.co.uk/news/article-5 224271/Manchester-fire-spread-wooden-balconies.html. Accessed 09 Sep 2020

23. London Fire Brigade (2010) West Hampstead Square, automatic fire suppression system activation case study. https://www.london-fire.gov.uk/media/3488/west-hampstead-s quare-afss-activation-case-study.pdf

24. The Haverling Daily (2019) The brown parts of the building went up so fast, i think it was the cladding. Then the glass exploded everywhere.-The Havering Daily. https://th ehaveringdaily.co.uk/2019/09/22/the-brown-parts-of-the-building-went-up-so-fast-i-thin k-it-was-the-cladding-then-the-glass-exploded-everywhere/. Accessed 09 Sep 2020

25. Trevithick M (2019) No injuries reported in west London balcony blaze: fire officials, GlobalNews.ca. https://globalnews.ca/news/5962810/london-balcony-blaze/. Accessed 09 Sep 2020

26. Hatherley T (2019) UPDATE: Sheppard Avenue reopens east of Don Mills after highrise fire, toronto.com https://www.toronto.com/news-story/9622151-update-sheppard-av enue-reopens-east-of-don-mills-after-high-rise-fire/. Accessed 09 Sept 2020

27. Lenk P, Sims L, Kent D, Dodd G, McIntyre E, Schulz J, Faudzi FBM, Laminated Glass Balustrade Queries [Interview], 07 Apr 2020

28. Li Y, Ren S (eds) 8 - Building Decorative Glass" in Building Decorative Materials, Woodhead Publishing, 2011, pp. 139-168

29. Aisha Dow, Combustible cladding to be stripped off Lacrosse Docklands tower, The Age, Jan. 17, 2017. https://www.theage.com.au/national/victoria/combustible-cladding-t o-be-stripped-off-lacrosse-docklands-tower-20170116-gtslcj.html. Accessed 09 Sep 2020

30. Richard Wheatstone, Ex-Chelsea boss Avram Grant describes how he ran for his life from inferno at his West London apartment block, The Sun, Jul. 03, 2018. https://ww w.thesun.co.uk/news/6686299/avram-grant-chelsea-west-ham-manager-hampstead-fire/.

Accessed 09 Sep 2020

31. Confidential Reporting on Structural Safety, "Newsletter No. 53 | January 2019," Jan. 2019. https://www.structural-safety.org/media/508220/cross-newsletter-no-53.pdf. Accessed 09 Sep 2020

Publisher's Note Springer Nature remains neutral with regard to jurisdictional claims in published maps and institutional affiliations. 